\title{
FORMULASI SIRUP EKSTRAK ETANOL DAUN PARE (Momordica charantia L.) DENGAN GELATIN SEBAGAI PENGENTAL DAN AKTIVITAS MUKOLITIKNYA
}

\author{
Ririn Lispita Wulandari ${ }^{* 1)}$, Eli Mahmud ${ }^{2)}$, Mufrod ${ }^{3)}$ \\ ${ }^{1}$ Bagian Farmakologi dan Farmasi Klinik, Fakultas Farmasi Universitas Wahid Hasyim \\ ${ }^{2}$ Fakultas Farmasi Universitas Wahid Hasyim \\ 3 Bagian Farmasetika dan Teknologi Farmasi, Fakultas Farmasi, Universitas Gadjah Mada \\ Jl. Menoreh Tengah X/22, Sampangan, Semarang \\ Email: ririnlispita88@gmail.com
}

\section{INTISARI}

Ekstrak etanol daun pare pada konsentrasi 5\% telah terbukti memiliki aktivitas mukolitik. Untuk memudahkan penggunaan maka dibuat bentuk sediaan sirup. Bahan pengental berfungsi untuk meningkatkan viskositas dan menahan proses pengenapan sehingga menghasilkan sirup yang stabil. Gelatin memiliki kemampuan memperbaiki pengenapan ekstrak lebih baik dibandingkan bahan pengental lainnya. Penelitian ini bertujuan untuk membuktikan pengaruh gelatin terhadap sifat fisika-kimia dan aktivitas mukolitik sirup ekstrak etanol daun pare (EEDP) pada mukus usus sapi secara in vitro. Ekstraksi daun pare dilakukan secara perkolasi. EEDP dibuat menjadi tiga formula sirup menggunakan pengental gelatin konsentrasi 1\% (FII), $2 \%$ (FIII), 3\% (FIV). Ada pula sirup tanpa ekstrak dan gelatin (FI) sebagai kontrol. Keempat formula sirup diperiksa sifat fisika kimia (organoleptis, homogenitas, $\mathrm{Ph}$, viskositas), dan diuji aktivitas mukolitiknya. Data hasil pemeriksaan organoleptis, homogenitas, $\mathrm{Ph}$ dianalisis deskriptif, sedangkan viskositas dengan Regresi Linier. Data hasil uji aktivitas berupa viskositas dianalisis Kruskal-Wallis dilanjut dengan Mann-Whitney. Hasil penelitian menunjukan bahwa sirup EEDP dengan konsentrasi gelatin 1\%; 2\%; $3 \%$ memiliki aktivitas mukolitik. Hasil pemeriksaan sifat fisika-kimia terhadap sirup FII, III, dan IV memiliki rasa dan warna sama yaitu manis dan pahit, dan berwarna hitam kehijauan, sedangkan sirup FI berasa manis dan berwarna kekuningan. sirup FI homogen, sirup FIII dan FIV terdistribusi merata, sedangkan sirup FII terdapat partikel kasar. pH keempat formula sirup normal. Peningkatan konsentrasi gelatin $(1 \% ; 2 \% ; 3 \%)$ dapat menaikkan viskositas sirup.

Kata kunci : ekstrak etanol daun pare, sirup, gelatin

\begin{abstract}
Ethanol extract of bitter melon leaves at a concentration of 5\% has been shown to have mucolytic activity. For ease of use that is made of dosage forms syrup. Thickening agent serves to increase the viscosity and resist settling process resulting in a stable syrup. Gelatin has the ability to improve settling extract better than other thickening. This study aims to determine the effect of variations in the concentration of gelatin to the physical-chemical properties and activity of ethanol extract syrup mukolitik pare leaves the cow intestine mucus in vitro.

Extraction of leaf bitter melon is done by percolation. EEDP was made into three syrup formulas using 1\% (FII), 2\% (FIII), 3\% (FIV) gelatin thickener. There is also syrup without extract and gelatin (FI) as a control. The four syrup formulas were examined for physical chemical properties (organoleptic, homogeneity, $\mathrm{pH}$, viscosity), and tested their mucolytic activity. Data on the results of activity tests in the form of viscosity were analyzed by Kruskal-Wallis followed by
\end{abstract}


Mann-Whitney. Data from organoleptic examination, homogeneity, $P h$ were analyzed descriptively, while viscosity with Linear Regression.

The results showed that EEDP syrup with a gelatin concentration of 1\%; $2 \% ; 3 \%$ have mucolytic activity. The results of examination of the physico-chemical properties of FII, III, and IV syrups have the same taste and color, sweet and bitter, and are greenish black in color, while FI syrup is sweet and yellowish in color. Homogeneous FI syrup, FIII and FIV syrup are evenly distributed, while FII syrup has coarse particles. Fourth $\mathrm{pH}$ normal syrup formula. Increased concentration of gelatin $(1 \% ; 2 \% ; 3 \%)$ can increase the viscosity of syrup

Keywords: ethanol extract of bitter melon leaves, syrup, gelatin

Corresponding author:

Ririn Lispita Wulandari

Fakultas Farmasi Universitas Wahid Hasyim

Jl. Menoreh Tengah X/22, Sampangan, Semarang

Email: ririnlispita88@gmail.com

\section{PENDAHULUAN}

Indonesia kaya akan tanaman obat yang berkhasiat sebagai obat batuk khususnya yang bermanfaat sebagai mukolitik atau pengencerdahak (Aprilina, 2013). Daun pare diketahui dapat digunakan sebagai obat batuk. Penelitian Asrofi $(2014)$ membuktikan bahwa aktivitas mukolitik EEDP $5 \%$ sebanding dengan asetilsistein $0,2 \%$, serta mengandung saponin, flavonoid, dan polifenol yang dapat membantu mengencerkan dahak.

Sirup merupakan sediaan cair berupa larutan yang mengandung sukrosa (DepKes RI, 1979). Pembuatan sediaan ini dapat ditambah perasa, aroma, dan pewarna agar menarik minat pasien. Sediaan ini juga dikenal lebih disukai oleh pasien yang memiliki kesulitan dalam menelan (Ansel et al., 1989).

Dalam pengembangan obat herbal menjadi sediaan sirup, kendala yang sering dihadapi adalah sulit menghasilkan sediaan yang terpenuhi syarat sifat fisik dan kimia karena dapat berpengaruh terhadap bioavailibilitas bahan aktif obat.

Ekstrak cair dan kental dapat digunakan untuk membuat sediaan cair, namun ekstrak bersifat sukar larut dalam larutan karena dapat terdispersi membentuk partikel kasar makauntuk membuat sediaansirup dibutuhkan bahan tambahan pengental(Rowe et al., 2009). Penggunaan bahan pengental dalam sirup dapat dilakukan untuk meningkatkan viskositas dan memperlambat atau menahan proses pengenapan sehingga menghasilkan sirup yang stabil (Nash, 1996)

Salah satu bahan pengental adalah gelatin, gelatin memiliki kemampuan memperbaiki pengenapan ekstrak lebih baik dibandingkan bahan pengental lainnya. Menurut Ward dan Court (1997) menyebutkan bahwa pada konsentrasi gelatin 1-9\% dapat meningkatkan viskositas sirup.

Oleh karena itu, penelitian terhadap formulasi sirup ekstrak etanol daun pare menggunakan gelatin sebagai pengental dan pemeriksaan sifat fisika-kimia serta aktivitas mukolitiknya perlu dilakukan.

\section{METODE PENELITIAN \\ Bahan Penelitian}

Daun pare yang diperoleh dari hasil budidaya di daerah Desa Wringin Putih, Kecamatan Bergas Kabupaten Semarang, etanol 96, sukrosa, metil paraben, gelatin, esens, gliserin, mukus dari usus sapi, $\mathrm{KH}_{2} \mathrm{PO}_{4}$ p.a, $\mathrm{NaOH}$ p.a, tween 80 .

\section{Alat Penelitian}

Blender, oven, ayakan mesh 25, timbangan elektrik (Ohaus), rotary evaporator dan moisture balance, batang pengaduk, sendok sungu, cawan,mortier dan stamper, kompor, timbangan elektrik, $\mathrm{pH}$ meter (SchottInstrument), alat-alat gelas (IwakiPyrex), stopwatch, viscometer ostwald, piknometer, inkubator. 


\section{JALANNYA PENELITIAN \\ 1. Pengumpulan Bahan}

Daun pare diperoleh dari Desa Wringin Putih, Kecamatan Bergas Kabupaten Semarang. yang dipanen di pagi hari, berumur sekitar 5 bulan, berwarna hijau, dan berukuran sedang.

\section{Pembuatan Ekstrak.}

Ekstrak etanol daun pare (EEDP) diperoleh dengan cara perkolasi. Bahan-bahan padat (serbuk) dibasahi dengan etanol 96\% (pelarut spesifik) dan didiamkan selama 4 jam di dalam suatu wadah yang tertutup. Campuran tersebut kemudian dimasukkan ke dalam perkolator yang sebelumnya bagian ujung berbentuk kerucut dimasukkan kapas yang berfungsi sebagai penahan sekaligus filter dari simplisia. Bagian atas simplisia kemudian ditutup menggunakan kertas saring. Setelah ditambahkan pelarut hingga ketinggian $\pm 1 \mathrm{~cm}$ di atas kertas saring, Pelarut ditambahkan untuk membentuk suatu lapisan dangkal di atas massa dan campuran itu dibiarkan dalam waktu 24 jam. Setelah didiamkan kran perkolator dibuka dan cairan diatur menetes secara perlahan. Cairan yang menetes melalui kran ditampung menggunakan erlenmeyer. Bila cairan penyari hanya tersisa selapis diatas permukaan simplisia, maka etanol ditambahkan sampai batas lapisan kertas saring \pm $3 \mathrm{~cm}$ diatasnya. Menstruum tambahan ditambahkan sesuai yang diperlukan, sampai ukuran perkolat tiga perempat dari volume yang diperlukan untuk menyelesaikan produk akhir, ekstrak cair tersebut kemudian diuapkan dengan rotary evaporator (Handa, 2008).

\section{Pembuatan Sirup}

a. Formula Sirup

Seri konsentrasi gelatin sebagai pengental dalam formula sirup ditetapkan 1\%, 2\%, $3 \%$ berdasarkan Ward dan Court (1997) yang menyebutkan bahwa pada konsentrasi gelatin 1-9\% dapat meningkatkan viskositas sirup. Formula sirup EEDP tersaji pada tabel I.

Tabel I. Formula Sirup EEDP Dengan Gelatin Sebagai Pengental (Komposisi tiap $60 \mathrm{~mL}$ Sirup)

\begin{tabular}{|c|c|c|c|c|c|c|}
\hline \multirow{2}{*}{ Komponen } & \multirow{2}{*}{ Satuan } & \multicolumn{4}{|c|}{ Konsentrasi (\%) dalam formula } & \multirow[t]{2}{*}{ Fungsi bahan } \\
\hline & & $\mathrm{I}$ & II & III & IV & \\
\hline Ekstrak daun pare & $\mathrm{g}$ & - & 5 & 5 & 5 & bahan utama \\
\hline sukrosa & $\mathrm{g}$ & 60 & 60 & 60 & 60 & pemanis \\
\hline Gelatin & $\mathrm{g}$ & - & 1 & 2 & 3 & pengental \\
\hline Gliserin & $\mathrm{ml}$ & 5 & 5 & 5 & 5 & pelarut \\
\hline Metil paraben & $\mathrm{g}$ & 0,25 & 0,25 & 0,25 & 0,25 & pengawet \\
\hline Esens & $\mathrm{g}$ & 5 & 5 & 5 & 5 & pengaroma \\
\hline Aquadest (ad) & $\mathrm{ml}$ & 60 & 60 & 60 & 60 & pelarut \\
\hline
\end{tabular}

Keterangan:

FI : sirup tanpa ekstrak etanol daun pare dan gelatin (kontrol)

F II : sirup EEDP menggunakanpengental gelatin 1\%

F III : sirupEEDP menggunakan pengental gelatin $2 \%$

F IV : sirupEEDP menggunakan pengental gelatin $3 \%$

\section{b. Formulasi sirup}

Formulasi sirup dilakukan dengan metode larutan bantuan panas yaitu caranya sebagai berikut: Masing-masing bahan utama, pemanis, pengental, pelarut, pengawet, pengaroma, dan pelarut ditimbang sesuai perhitungan. Pembuatan sirup EEDP (FII, FIII dan FIV) dimulai dengan memasukkan EEDP ke dalam mortir dan ditambah metil paraben aduk rata, tahapan selanjutnya pembuatan mucilago gelatin dengan cara didispersikan gelatin dalam sebagian gliserin dan air sampai terbentuk cairan yang kental dan jernih. Setelah itu, pembuatan sirup sukrosa dengan cara melarutkan sukrosa dan air dengan bantuan panas tunggu agak dingin. Ditambahkan gelatin yang telah didispersikan dan sirup sukrosa ke dalam EEDP, kemudian diaduk hingga homogen. Untuk FI tidak melakukan tahapan memasukkan EEDP dan gelatin, Tahap akhir adalah penambahan pengaroma esens kemudian dihomogenkan lalu dicukupkan volumenya dengan aquadest hingga $60 \mathrm{ml}$ (Amry, 2014). 


\section{Pemeriksaan Sifat Fisika dan Kimia}

a. Uji organoleptis

Sirup EEDP diperiksa menggunakan panca indra atau tanpa alat bantu terhadap aroma, rasa, warna sediaan (Charter, 1997).

b. Uji Homogenitas

Sirup EEDP diperiksa dengan cara dituangkan pada kaca transparan, lalu bagian yang tidak tercampurkan dengan baik diamati (Charter, 1997).

c. Pengukuran $\mathrm{pH}$

$\mathrm{pH}$ sirup EEDP diukur menggunakan alat $\mathrm{pH}$ meter. Sebelum digunakan untuk mengukur $\mathrm{pH}$ sirup, alat tersebut dikalibrasi, dicelupkan ke dalam larutan buffer $\mathrm{pH} 7$, lalu dibilas aquadest. Setelah itu, $\mathrm{pH}$ meter dicelupkan ke dalam sediaan uji, didiamkan beberapa waktu dan hasilnya terlihat pada angka yang muncul di layar (Murrukmihadi et al., 2011).

d. Pengukuran Viskositas

Pengukuran viskositas dilakukan menggunakan viskometer Ostwald. Viskositas sediaan uji dihitung menggunakan rumus sebagai berikut (Sinko, 2006).

\section{Viskositas $=\frac{\rho \text { Sampextsample }}{\rho \text { air suling } x \text { tair suling }} X \boldsymbol{\eta}$ air suling $25^{\circ}$}

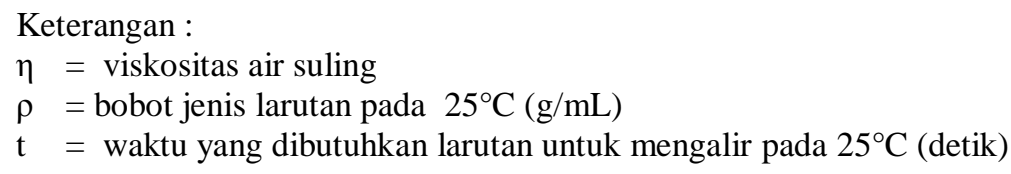

\section{Pengujian Aktivitas Mukolitik}

\section{a. Penyiapan Bahan Uji}

Larutan Dapar Fosfat :

Pembuatan larutan dapar fosfat dilakukan dengan cara $\mathrm{KH}_{2} \mathrm{PO}_{4}$ (p.a) $0,20 \mathrm{M}$ sebanyak 25,0 $\mathrm{ml}$ dicampur dengan $14,55 \mathrm{ml} \mathrm{NaOH}$ (p.a) $0,20 \mathrm{M}$, lalu dimasukkan ke dalam labu takar, ditambahkan air bebas $\mathrm{CO}_{2}$ sampai $100 \mathrm{ml}$, kemudian di cek pHnya menggunakan $\mathrm{pH}$ meter sampai didapatkan $\mathrm{pH} 7,00$.

Larutan Mucus 20\%:

Pembuatan larutan mucus $20 \% \mathrm{~b} / \mathrm{b}$ dalam dapar fosfat dilakukan dengan cara mukus sebanyak 20 bagian (dalam bobot) dicampur dengan dapar-fosfat $\mathrm{pH} 7$ sebanyak 80 bagian (dalam bobot) sehingga total 100 bagian (dalam bobot).

\section{b. Uji aktivitas mukolitik}

Sirup FI, FII, FIII, FIV masing-masing ditambahkan larutan mukus-dapar fosfat dengan perbandingan 1:1 (dalam bobot). Sebanyak $15 \mathrm{~g}$ sirup dicampur $0,5 \% \mathrm{~b} / \mathrm{b}$ bobot total atau $0,15 \mathrm{~g}$ tween 80 . Selanjutnya larutan mukus-dapar fosfat ditambahkan ke dalam campuran tersebut hingga bobot total sebesar $30 \mathrm{~g}$ dan diaduk sampai campuran homogen, lalu agar kondisi terjadinya reaksi pada sirup sesuai dengan kondisi fisiologis pada manusia maka diinkubasi selama 30 menit pada suhu $37^{\circ} \mathrm{C}$, lalu dilakukan pengukuran viskositasnya. Pengukuran viskositas dilakukan menggunakan alat Viskometer Ostwald. Sediaan uji sebanyak $10 \mathrm{~mL}$ dimasukkan ke dalam alat tersebut. Kemudian dinaikkan menggunakan pompa hingga permukaannya berada pada bagian menggelembung di atas batas garis atas Ostwald. Saat permukaan sirup sudah berada di garis batas bagian atas pompa dilepaskan dan penghitungan waktu dengan stopwatch dimulai. Saat permukaan sediaan uji telah mencapai batas bawah, penghitungan waktu dengan stopwatch dihentikan. Waktu yang dihasilkan selama permukaan sirup bergerak dari garis batas atas sampai garis batas bawah dicatat (waktu alir sirup). Bobot piknometer kosong terlebih dahulu ditimbang untuk pengukuran kerapatan. Sediaan uji kemudian dimasukkan ke dalam piknometer dan diinkubasi hingga suhunya mencapai suhu $37^{\circ} \mathrm{C}$. Saat suhu piknometer telah menunjukkan suhu $37^{\circ} \mathrm{C}$, segera piknometer ditutup dan ditimbang kemudian dicatat hasil penimbangan sebagai bobot sediaan uji dan piknometer. Bobot sediaan uji diperoleh dengan mengurangkan bobot sirup dan piknometer dengan bobot piknometer kosong. Viskositas 
sirup FI, FII, FIII, FIV dihitung menggunakan rumus dengan pembanding menggunakan air suling sebagai berikut (Murrukmihadi et al, 2011) :

Viskositas $=\frac{p \text { Sampext sample }}{p \text { afr suling } x t \text { afr suling }} X \quad \eta$ air suling $37^{\circ}$

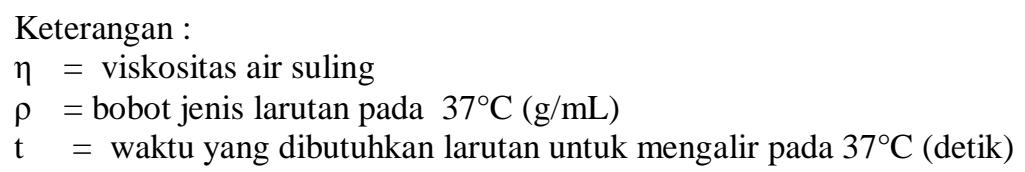

Hasil pengukuran viskositas sediaan uji dibandingkan dengan viskositas kontrol (FI).

\section{ANALISIS DATA}

\section{Pemeriksaan Sifat Fisika-Kimia}

Data sifat fisika-kimia sirup EEDP meliputi aroma, rasa, warna, homogenitas, pH dianalisis deskriptif, sedangkan viskositas dianalisis regresi linier sederhana.

\section{Uji aktivitas mukolitik}

Data yang diperoleh adalah viskositas sirup FI, FII, FIII dan FIV. Secara teori, sediaan uji mempunyai aktivitas mukolitik bila viskositasnya lebih kecil dan berbeda bermakna dibandingkan dengan kontrol (Windriyati, 2010). Data viskositas keempat formula sirup tersebut dianalisis statistik. Data viskositas dianalisis dengan uji Kruskall-Wallis, dilanjut uji Mann-Whitney untuk mengetahui perbedaan viskositas antar formula.

\section{HASIL dan PEMBAHASAN}

\section{a. Pemeriksaan Sifat Fisika-Kimia Sirup}

Setelah dilakukan pemeriksaan organoleptis terhadap sirup EEDP menunjukan bahwa semua sirup memiliki aroma yang sama yaitu aroma jeruk yang didapat dari penambahan essens jeruk Sirup FII, III, dan IV memiliki rasa dan warna sama yaitu manis dan pahit, dan berwarna hitam kehijauan, sedangkan sirup FI berasa manis dan berwarna kekuningan (tabel II). Perbedaan ini disebabkan sirup FI tidak menggunakan EEDP sedangkan sirup FII, FIII, FIV menggunakan EEDP.

Tabel II . Hasil Uji Organoleptis Sirup

\begin{tabular}{cccc}
\hline Formula Sirup & Aroma & Rasa & Warna \\
\hline F I & Jeruk & Manis & jernih kekuningan \\
F II & Jeruk & manis,pahit & hitam kehijauan \\
F III & Jeruk & manis,pahit & hitam kehijauan \\
F IV & Jeruk & manis,pahit & hitam kehijauan \\
\hline
\end{tabular}

Keterangan:

FI : sirup tanpa ekstrak etanol daun pare dan gelatin (kontrol)

F II : sirup EEDP menggunakanpengental gelatin $1 \%$

F III : sirupEEDPmenggunakan pengental gelatin $2 \%$

F IV : sirupEEDP menggunakan pengental gelatin $3 \%$

Berdasarkan hasil uji homogenitas yang telah dilakukan didapat sirup FI homogen, sirup FIII dan FIV terdistribusi merata, sedangkan sirup FII terdapat partikel kasar (tabel III).

Tabel III. Hasil Uji Homogenitas Sirup

\begin{tabular}{ll}
\hline Formula Sirup & Homogenitas \\
\hline F I & Homogen \\
F II & terdapat partikel kasar \\
F III & terdistribusi merata \\
F IV & terdistribusi merata \\
\hline
\end{tabular}




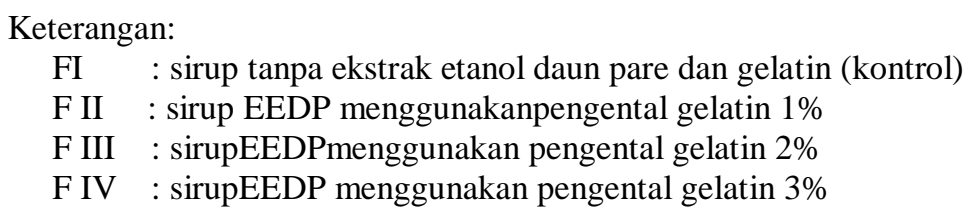

Hasil pengukuran $\mathrm{pH}$ terhadap semua formula sirup menghasilkan $\mathrm{pH}$ masuk rentang nilai $\mathrm{pH}$ yang disyaratkan untuk suatu sediaan sirup yaitu berkisar antara $4-7$ (tabel IV). Pengukuran $\mathrm{pH}$ merupakan faktor penting di dalam formulasi karena dapat mempengaruhi kelarutan obat, aktivitas, absorbsi, stabilitas, dan kenyamanan pasien (Allen etal., 2002). Nilai pH yang dianjurkan untuk sirup adalah berkisar antara $4-7$ (DepKes, 1995).

Tabel IV. Hasil Pengukuran pH Formula Sirup

\begin{tabular}{ll}
\hline Formula Sirup & $\mathbf{p H}$ \\
\hline F I & 6,37 \\
F II & 5,63 \\
F III & 5,79 \\
F IV & 5,81 \\
F V & 5,80 \\
\hline
\end{tabular}

Keterangan:

FI : sirup tanpa ekstrak etanol daun pare dan gelatin (kontrol)

F II : sirup EEDP menggunakan pengental gelatin $1 \%$

F III : sirupEEDP menggunakan pengental gelatin $2 \%$

F IV : sirupEEDP menggunakan pengental gelatin 3\%

Hasil pemeriksaan sifat fisik yaitu viskositas sirup EEDP diketahui berdasarkan nilai waktu alir yang diperoleh setelah pengujian menggunakan viskometer ostwald. Data waktu alir dan viskositas tersaji pada tabel IV.

Tabe IV.Hasil Pengukuran Viskositas Formula Sirup Ekstrak Etanol Daun Pare

\begin{tabular}{|c|c|c|}
\hline Formula & Waktu alir & Viskositas (cps) \\
\hline F II & 2’08’18 =1,942 & $26,38 \pm 0,395$ \\
\hline F III & $3^{\prime} 05^{\prime} 37 \pm 1,963$ & $38,44 \pm 0,403$ \\
\hline F IV & $3^{\prime} 52 ’ 13 \pm 2,842$ & $48,15 \pm 0,585$ \\
\hline
\end{tabular}

Data viskositas yang tersaji pada tabel IV kemudian di uji regresi linier berguna mengetahui pengaruh berbagai konsentrasi gelatin terhadap viskositas. Hasil uji menunjukan bahwa semakin besar konsentrasi gelatin dalam formula sirup, membuat semakin tinggi viskositas sirup EEDP (gambar 2). Hal ini terjadi diduga disebabkan karena gelatin mampu mengikat air sehingga sirup menjadi kental (Ayudiarti, 2007).

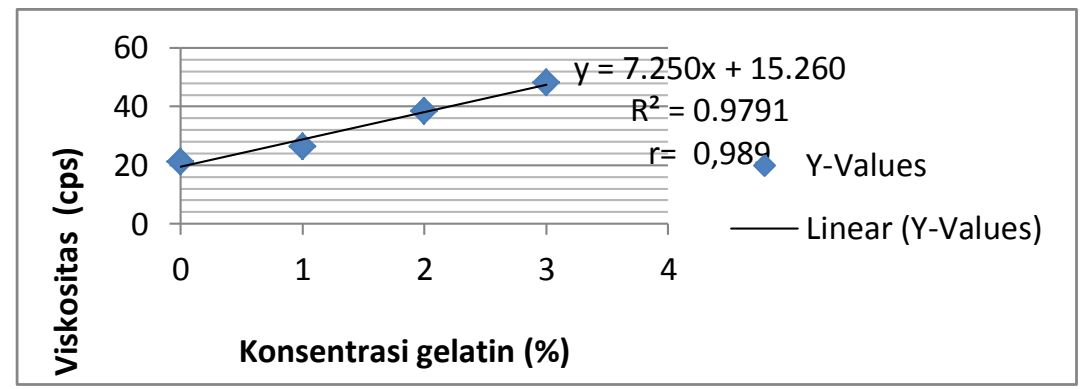

Gambar 2. Pengaruh peningaktan konsentrasi gelatin terhadap viskositas ketiga formula Sirup EEDP 


\title{
b. Uji Aktivitas Mukolitik Sirup EEDP
}

Sirup FII, FIII, dan FIV memiliki viskositas lebih kecil dan berbeda bermakna dibandingkan dengan kelompok kontrol (gambar 3). Hasil uji statistik Kruskal Wallis terhadap data viskositas dengan taraf kepercayaan $95 \%$ dan didapat hasil nilai signifikasi $0,025<0,05$ artinya terdapat perbedaan yang bermakna diantara larutan uji, sehingga diteruskan uji Mann Whitney. Uji tersebut dilakukan untuk mengetahui perbedaan aktivitas mukolitik antarformula sirup EEDP. hasil uji Mann whitney bahwa FI berbeda bermakna dengan FII, FIII dan FIV. Sirup FIII dan FIV tidak berbeda bermakna. Hal ini terjadi mungkin disebabkan penggunaan pengental dalam rentang konsentrasi yang tidak berbeda jauh. Asrofi (2014) menyebutkan bahwa ekstrak etanol daun pare memiliki senyawa aktif berupa saponin, polifenol dan flavonoid yang memiliki aktivitas mukolitik. Menurut Evans (2002) menyebutkan bahwa pemecahan benang-benang mukoprotein dan mukopolisakarida sputum (mukus) disebabkan oleh aksi dari senyawa polifenol dan flavonoid. Berbagai macam jenis ikatan antar molekul terdapat di dalam mukus. Gugus aktif dari senyawa aktif dapat memutus ikatan disulfida mukus sehingga viskositas mukus dapat diturunkan. Saponin bekerja dengan cara menstimulasi secret keluar dari bronkial dan meningkatkan aktivitas epitel yang bersilia, yang dapat menstimulasi batuk agar dahak dikeluarkan. Senyawa-senyawa aktif tersebut memiliki aktivitas mukolitik seperti penelitian Windriyati (2010) dan Wulandari (2013) dalam ekstrak daun sirih merah.

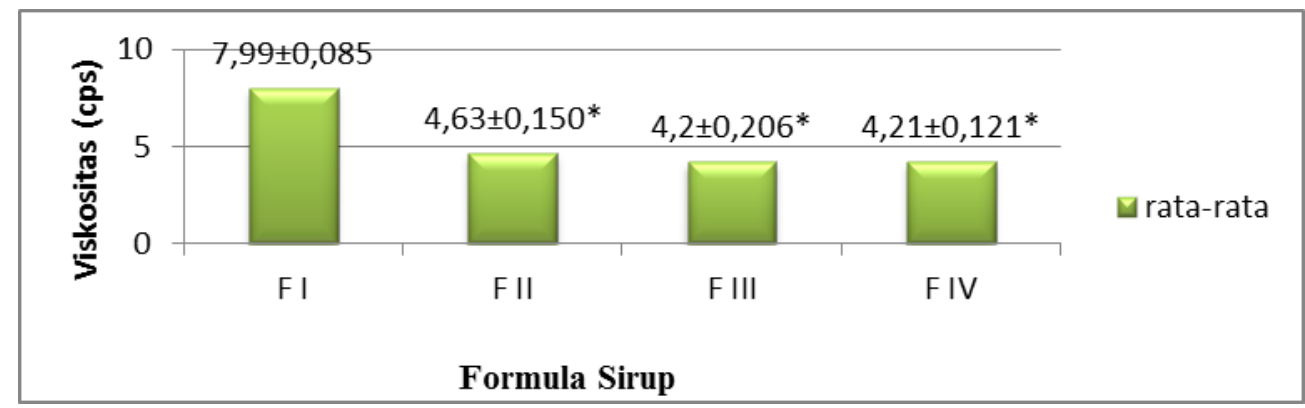

Gambar 3. Hasil uji Mann Whitney terhadap Viskositas Formula Sirup Ekstrak Etanol Daun Pare

\author{
Keterangan: \\ *:berbeda bermakna terhadap kontrol ( $p<0,05$, uji Mann Whitney) \\ FI : sirup tanpa ekstrak etanol daun pare dan gelatin (kontrol) \\ F II: sirup EEDPmenggunakan pengental gelatin $1 \%$ \\ F III : sirupEEDP menggunakan pengental gelatin $2 \%$ \\ F IV : sirup EEDPmenggunakan pengental gelatin $3 \%$
}

\section{KESIMPULAN}

1. Variasi konsentrasi gelatin $1 \% ; 2 \% ; 3 \%$ dapat mempengaruhi sifat fisika kimia sirup ekstrak etanol daun pare yaitu organoleptis (aroma, rasa dan warna), homogenitas, $\mathrm{pH}$, dan viskositas.

2. Sirup ekstrak etanol daun pare dengan konsentrasi gelatin $1 \% ; 2 \% ; 3 \%$ memiliki aktivitas mukolitik terhadap mukus usus sapi secara in vitro.

\section{DAFTAR PUSTAKA}

Allen LV, 2002, The Art, Science and Technology of Pharmaceutical Compounding, Second Edition, Washington D.C, 170-173, 183,187

Amry K, 2014, Formulasi dan Uji Stabilitas Fisik Sediaan Sirup Kombinasi Ekstrak Air Daun Paliasa (kleinhovia hospita linn.) dan Rimpang Temulawak (Curcuma xanthorriza roxb.) Skripsi, Universitas Hasanuddin, Makassar 
Ansel HC, 1989, Pengantar Bentuk Sediaan Farmasi , Edisi ke IV., diterjemahkan Farida Ibrahim, Universitas Indonesia Press. Jakarta, 162-163, 357-389.

Asrofi I, 2014, Uji Aktivitas Mukolitik Ekstrak Etanol Daun Pare (Momordica charantia 1.) dengan Metode Perkolasi Pada Mukus Usus Sapi Secara in vitr oDan Identifikasi Kandungan Kimianya, Skripsi, Universitas Wahid Hasyim, Semarang.

Aprilina F, 2013,Profil Penggunaan Obat Tradisional Pada Masyarakat Di Kabupaten Tabalong Kalimantan Selatan Tahun 2013, Naskah Publikasi, Fakultas Farmasi,Universitas Muhammadiyah urakarta

Ayudiarti DL, Suryati, Tazwir, Paranginangin, R., 2007, Pengaruh Konsentrasi Gelatin Ikan Sebagai Bahan Pengikat Terhadap Kualitas dan Penerimaan Sirup, Jurnal Perikanan, (J. Fish.Sci.) IX (1) :134-141

Charter JS, 1997, Dispensing for Pharmaceutical Student, Edisi ke-12, Pitman Medical: London10, 186-187

DepKes RI, 1979, Farmakope Indonesia, Edisi III, Departemen Kesehatan Republik Indonesia, Jakarta,

DepKes RI, 1995, Farmakope Indonesia, Edisi Keempat, Departemen Kesehatan Republik Indonesia, Jakarta,

Evans, WC., 2002, Pharmacognosy, $15^{\text {th }}$ Eds,W.B.Sunders, 289-299, New York.

Handa SS., 2008, Extraction Technologies for Medicinal and Aromatic Plants, United Nations Industrial Development Organization and the International Centre for Science and High Technology, Italy, 22-23

Murrukmihadi, M., Wahyuono, S,Marchaban, Martono, S., 2011, Optimasi Formulasi Sirup Fraksi Tidak Larut Etil Asetatyang Mengandung Alkaloid Dari Bunga Kembang Sepatu (Hibiscus rosa-sinensis L.),Majalah Obat Tradisional, Fakultas Farmasi Universitas Gadjah Mada Yogyakarta,16(2), $101-108$

Rowe, RC., Paul, J., Sheskey, and Sian C., Owen, 2009, Handbook of Pharmaceutical Exicipients., Sixth Edition, , Pharmaceutical Press, London, Chicago.

Sinko, PJ., 2006, Martin's Physical Pharmacy and Pharmaceutical Science: Physical Chemical and Biopharmaceutical Principle in the Pharmaceutical Sciences, $5^{\text {th }}$ edition, Philadelpia, 428-430.

Ward, AG. and A. Courts, 1997, the science and technology of gelatin, Academic press

Windriyati, YN, Murrukmihadi, M, Junita, NR, 2010, Aktivitas Mukolitik In Vitro Ekstrak Etanolik Herba Meniran (Phyllantus Niruri L) Terhadap Mukosa Usus Sapi, jurnal ilmu farmasi dan farmasi klinik, FakultasFarmasi, Universitas Wahid Hasyim Semarang, Volume $7: 1-3$

Wulandari, RL, Windriyati, YN, Budiarty, A, 2013, Aktivitas Mukolitik Fraksi Metanol Dari Ekstrak Etanol Daun Sirih Merah (Piper Crocotum Ruiz And Pav.) Pada Mukosa Usus Sapi Dan Kandungan Kimianya, jurnal ilmu farmasi dan farmasi klinik, Fakultas Farmasi, Universitas Wahid Hasyim Semarang, Volume 10 No:1 